УДК 658.513.012.12

С.К. Мещанінов, д.т.н. професор

Дніпровський державний технічний університет, м. Кам'янське

\title{
МАТЕМАТИЧНА МОДЕЛЬ ЕЛЕКТРОННОЇ СИСТЕМИ КОНТРОЛЮ ПСИХОФІЗІОЛОГІЧНОГО СТАНУ МАШИНІСТА ЛОКОМОТИВНОГО СКЛАДУ
}

У статті розглядається питання створення методу контролю психофізіологічного стану машиніста локомотивного складу в режимі реального часу, що можливо на основі використання математичної моделі даного прочесу, а також обтрунтування набору інформативних параметрів такого контролю. Модель враховує індивідуальні особливості людини $і$ здатна максимально адекватно оцінювати психофізіологічний стан машиніста локомотивного складу при мінімально задіяних ресурсів.

Ключові слова: психофізичний стан, обробка мовного сигналу, набір інформативних параметрів, машиніст локомотивного складу, система контролю.

The article considers the question of creating a method for monitoring the psychophysiological state of a locomotive train driver in real time, which is possible on the basis of using the mathematical model of this process, as well as justifying a set of informative parameters for such control. The model takes into account the individual characteristics of a person and is able to adequately assess the psychophysiological condition of the locomotive driver with the minimum resources involved.

Keywords: psychophysical state, processing of a speech signal, set of informative parameters, locomotive driver, control system.

\section{Постановка проблеми}

На сьогодні, серед працівників залізничного складу, машиніст є найбільш відповідальною людиною, на яку доводиться «левова» частка усієї інформації, що поступає з боку як зовнішніх джерел, так і внутрішніх чинників. Тому в умовах інтенсифікації праці на залізничному транспорті все частіше виникає проблема безперебійного контролю за ПФС машиніста без використання контактних приладів виміру.

Необхідність контролю ПФС машиніста 3 метою підвищення рівня продуктивності і зменшення міри ризику здоров'ю і загрозі життя пасажирів і персоналу, обслуговуючого перевезення, представляється дуже актуальним і своєчасним. Це обумовлено, в першу чергу тим, що інтенсифікація виробничих процесів на залізниці, підвищення швидкостей і навантажень на залізничний склад і рейковий шлях ставить питання надійності і безпеки цих процесів на принципово новий рівень. Крім того, дуже важливим тут також представляється і те, що сам ритм життя сучасної людини змінився за останні декілька десятиліть. Ці чинники негативно впливають на ПФС людини, що, у свою чергу, висуває підвищені, i, часто, якісно інші вимоги до дій i відповідальності людини-оператора, в нашому випадку - машиніста локомотивного складу. Одним з основних шляхів вирішення цієї проблеми є створення методу контролю ПФС машиніста в режимі реального часу, що можливо на основі використання математичної моделі цього процесу, а також обгрунтування набору інформативних параметрів такого контролю.

\section{Формулювання мети дослідження}

Таким чином, метою справжньої роботи є створення математичної моделі з метою отримання максимально адекватної оцінки ПФС людини при мінімально задіяних ресурсів.

\section{Виклад основного матеріалу}

Аспектом проблеми дослідження психофізичного стану людини займалися вчені на протязі не одного століття. Нині існує декілька способів у біометрії за визначенням психофізичного стану людини, а саме: віброзображення, електроміографія(ЭМГ), реєстрація шкірногальванічної реакції (КГР), реєстрація імпульсної активності нервових клітин [1], детектор брехні і його окремі складові [2]. 
Найбільша увага приділяється такому методу, як віброзображення. Він сприяє діагностуванню, де застосовні рух голови і очей [3], які інформаційно характеризують стан людини шляхом накопичення параметрів вібрації для кожної частини (пікселя) випробовуваного [4]. Детально про це описано в монографії Г. Тамара [5], де особлива увага приділяється матеріалу об гальмування в сенсорних системах. Але цей метод не $є$ доцільним і має ряд обмежень : висока якість зображення, широка смуга частот і швидка передача інформації об оцінки психофізичному стан людини (ПФС) на віддалені відстані [6]. Відносно ж методу ЭМГ, КГР, то він являється недосконалий виходячи з ряду параметрів : контактність приладів (що далеко не завжди можливо), безперервність вимірів, трудність в швидкості оцінки ПФС. Тому багато хто перейшов на вивчення інших параметрів людини, по яких можна було б визначити його реакції i емоції. Велика кількість досліджень на сьогодні проводиться в області обробки мовного сигналу [7]. Однією з найбільших переваг, якої залишається використання безконтактного датчика, а за рахунок мінімальних розмірів самого мікрофону, здібної приховати від уваги людини надається можливість приміщення суб'єкта у буденну, робочу обстановку і дослідження спонтанної мови в реальних умовах [8]. Це допомагає мінімізувати вірогідність погрішності пристрою, яка викликає значну психологічну і фізичну дію на випробовуваного при використанні контактного датчика. Проте, проаналізувавши цей метод з тими або іншими параметрами ставати ясно, що проблема діагностики і моніторингу ПФС людини далека від рішення.

Тому представляється актуальним: створити систему здатну контролювати ПФС машиніста в режимі реального часу з урахуванням індивідуальних особливостей людини в течії робочої зміни із застосуванням безконтактного датчика.

Для цього треба:

1. Встановити в рацію машиніста мікрофон з високим рівнем завадо захищеності. Мікрофон повинен записувати голос працівника і передати необхідні дані на комп'ютер. Для точнішої оцінки ПФС машиніста можна також застосувати лазерний цифровий термометр. Голос як основний показник наявності стресового стану або перевтоми був вибраний усвідомлено. Дослідження по вивченню впливу ПФС на мову людини ведуться вже давно. Н.В. Геладзе [9] стверджував, що при смутку, і страху тембр голосу з нейтрального починає збільшуватися, а при радості, гніві, роздратуванні - зменшуватися. Деякі учені [10] відмічають, що існує п'ять стійких станів: норма, гнів, депресія, радість, тривога. Але В. В. Потапову і Р. Д. Потаповій [11] вдалося експериментально довести, що існує дві стійкі емоції - «страх» і «тривожність».

2. Розробити програмне забезпечення для обробки мовного сигналу. Для встановлення граничних значень кожного з вибраних параметрів необхідно запис голосу машиніста перед зміною. Отримані дані зіставлятимуться з поточними протягом всього часу зміни. Вважаємо, що контролюватися повинні наступні параметри:

- посилення або зменшення тембру голосу. Впродовж певного інтервалу часу знімаються свідчення машиніста. Від максимального значення $Q_{\max }$ віднімається погрішність $\delta \_\mathrm{Q}$ і віднімається погрішність $\delta_{Q}$ и $\sum_{i=1}^{n} L_{i}$ і сума сторонніх шумів (для чистоти звучання), набуваємо еталонного або порівняльного значення $Q_{c r}$

$$
Q_{c r}=Q_{\max }-\left(\delta_{Q}+\sum_{i=1}^{n} L_{i}\right),
$$

де $Q_{\max }$ - максимальне («порогове») значення тембру голосу; $\delta_{Q}$ - погрішність свідчень виміру; $\sum_{i=1}^{n} L_{i}$ - сума шумів $i$-ої гармоніки.

Якщо при зіставленні даних $Q<Q_{c r}$ перевищення значне, це свідчить про те, що ПФС відхилене від норми, в наслідку втоми або підвищеної агресивності і працівника необхідно замінити.

Якщо при порівнянні даних $Q>Q_{c r}$ перевищує порогове значення, це означає, що машиніст знаходиться в пере збудженому стані або в стані алкогольного сп'яніння і потрібне усунення від роботи. 
- темп мови. Впродовж певного інтервалу часу знімаються свідчення машиніста. Від максимального значення $G_{\max }$ віднімається погрішність $\delta_{G}$ i $\sum_{i=1}^{n} L_{i}$ сума сторонніх шумів (для чистоти звучання), набуваємо еталонного або порівняльного значення $G_{c r}$.

$$
G_{c r}=G_{\max }-\left(\delta_{G}+\sum_{i=1}^{n} L_{i}\right),
$$

де $G_{\max }-$ максимальне («порогове») значення швидкості мови; $\delta_{G}-$ погрішність свідчень виміру; $\sum_{i=1}^{n} L_{i}-$ сума шумів $i$-ої гармоніки. уваги.

Якщо $G<G_{c r}$ то можна судити про погане самопочуття машиніста, втоми, неуважності

Якщо ж $G<G_{c r}$, то можна говорити про підвищену агресивному стані або про нестійкість психічного стану.

За умови $G=G_{c r}$, при порівняння інформації виходить, що стан машиніста відповідає нормі і він може виконувати поставлені завдання.

- ритм мови. Впродовж певного інтервалу часу знімаються свідчення машиніста. Цей параметр неможливо виміряти максимально точно без введення додаткового показника, а саме коефіцієнта дефектності мови $\chi_{d r}$. Цей коефіцієнт чисельно дорівнюватиме співвідношенню кількості сказаних слів в хвилину $N_{w}$ до кількості помилок в словах $\xi_{w}$.

$$
\chi_{d r}=\frac{N_{w}}{\xi_{w}}
$$

де $\chi_{d r}$ - коефіцієнт дефектності мови; $N_{w}$ - кількість сказаних слів в хвилину; $\xi_{w}$ - кількість помилок в словах.

Тоді для вимір ритму мови потрібний: отримати усереднене значення $R_{s}$, після чого від нього видаленням $\chi_{d r}$ - коефіцієнт дефективності мови і отримуємо еталон $R_{c r}$.

$$
R_{c r}=R_{s}-\chi_{d r}
$$

де $R_{s}$ - усереднене значення ритму мови; $\chi_{d r}$ - коефіцієнт дефектності мови.

Якщо при подальшому дослідженні $R<R_{c r}$, то свідчить про втому машиніста і підвищення рівня ризику (6).

Якщо ж $R>R_{c r}$, то можна говорити про стан сп'яніння машиніста, перезбудження або про нестійкий психічний або фізичний стан.

- точність вимови слів. Впродовж певного інтервалу часу знімаються свідчення машиніста. Визначається середнє значення $T_{s}$, від нього віднімається коефіцієнт дефектності мови $\chi_{d r} \mathrm{i}$ $\sum_{i=1}^{n} L_{i}$ і сума сторонніх шумів (для чистоти звучання), набуваємо еталонного або порівняльного значення $T_{c r}$.

$$
T_{c r}=T_{s}-\left(\chi_{d r}+\sum_{i=1}^{n} L_{i}\right),
$$

де $T_{s}$ - середнє значення точності вимови слів; $\chi_{d r}$ - коефіцієнт дефектності мови; $\sum_{i=1}^{n} L_{i}-$ сума шумів $i$-ої гармоніки.

Якщо при спостереження над випробовуваним $T<T_{c r}$, велика кількість часу, чим заданий інтервал $t_{i}$, , то можна зробити висновок, що машиніст знаходиться в пригніченому стані або перевтома.

- чіткість виконуваних команд згідно посадової інструкції і нормативних актів по охороні праці (ВІД). Впродовж певного інтервалу часу знімаються свідчення машиніста. Від максимального значення $J_{\max }$ віднімається погрішність $\delta_{J}$ отримуємо еталонне або порівняльне значення $J_{c r}$. Цей параметр береться залежно від кількості виконаної роботи і досвіду роботи машиніста.

$$
J_{c r}=J_{\max }-\delta_{J},
$$

де $J_{\max }$ - максимальне («порогове») значення помилок в хвилину; $\delta_{J}$ - погрішність свідчень виміру. 
Якщо при подальшому дослідженні $J>J_{c r}$, то можна говорити об перевтому, в результаті великих психічних навантажень.

3. Усю інформацію об стан здоров'я машиніста необхідно ввести в одну загальну базу доступ до якої знаходитиметься у начальника станції, мед. персоналу і диспетчера потягу.

4. Після проведення оцінки ПФС машиніста дані виводяться на монітор диспетчера потягу з подальшими рекомендаціями по ліквідації ситуації, що склалася, відбувається спрацьовування світлового індикатора. Для критичного стану краще всього використати червоний індикатор, оскільки він $є$ одним з їдких кольорів сприяючий розгальмуванню кори головного мозку і моментальну реакцію нейронів. Після чого диспетчер повинен оповістити по каналу радіолокації зв'язки про необхідну заміну співробітника.

Побудова системи контролю ПФС машиніста може розв'язати цю проблему, але з урахуванням розробки необхідного програмного забезпечення. Тому вважається необхідним створення математичної моделі для закріплення базових основ системи і розуміння чіткої структури.

Стан людини розглядаємо, як систему, яка з одного боку характеризується такими властивостями, як адитивність і інваріанівність, а з іншого боку — це система, яка під діями зовнішніх дій з часом змінює свої стани. Тобто ПФС людини $є$ динамічною, лінійною системою, $з$ певним набором параметрів. Тому найкраща назва їй $\lambda_{\text {ПФС. }}$ В якості вхідних параметрів слід використати параметри, що визначають стан здоров'я.

Таблиия 1. Вхідні параметри ПФС людини

\begin{tabular}{|l|l|}
\hline Найменування & Позначення \\
\hline Гострота зору & $\gamma 1$ \\
\hline Артеріальний тиск & $\gamma 2$ \\
\hline Частота дихальних рухів & $\gamma 3$ \\
\hline Сприйняття звуків & $\gamma 4$ \\
\hline Частота сердечних скорочень & $\gamma 5$ \\
\hline Метаболізм & $\gamma 6$ \\
\hline Амплітуда м'язових скорочень & $\gamma 7$ \\
\hline
\end{tabular}

Сумарне значення цих параметрів дасть можливість обчислення показника вхідної інформаційної дії показник системи, виходячи з нього і розроблятиметься спочатку система:

$$
S_{\mathrm{BX}}(t)=C \cdot\left(\sum_{a=1}^{k} \gamma_{a}(t)\right)=\sum_{a=1}^{k} \gamma_{a} \cdot C_{a}(t),
$$

де $a-$ індекс підсумовування; $k-$ верхня межа підсумовування; $\gamma_{a}, C_{a}-$ змінна, що означає кожен доданок в серії. рень):

На виході набуваємо значення параметрів змінених, після дії зовнішніх чинників (обу-

- кліматичних умов;

- екології;

- шкідливих умов роботи;

- схильності організму до метеозалежності;

- наявність стресу — чинника в організмі;

- психосоматичній розташованості нервової системи;

- адаптації до місцевості.

Умовно усі ці зовнішні причини дії на організм людини С можна поділити на три групи:

- первинні, ті, які здатні вражати організм в першу чергу $\eta=\operatorname{row}\left(\eta_{1}, \ldots . \eta_{n}\right)$;

- цільові ті, що сприяють поразка організму в цілому $\psi=\operatorname{row}\left(\psi_{1}, \ldots . \psi_{n}\right)$;

- стаціонарні ті, під впливам, яких відбувається постійні зміна здоров'я людини $\beta=\operatorname{row}\left(\beta_{1}, \ldots \beta_{n}\right)$. 
Вихідними параметрами вважаються, як загальну кількість «пошкоджених» вхідних, тобто зміна після дії зовнішніх обурень, на виході ми отримуємо загальний показник, який буде рівний:

$$
V_{\text {вых }}(t)=C \cdot\left(\sum_{j=1}^{n} V_{j}(t)\right)=\sum_{j=1}^{n} V_{j} \cdot C_{j}(t),
$$

де $j$ - індекс підсумовування; $n$ - верхня межа підсумовування; $V_{j}, C_{j}$ - змінна, що означає кожен доданок в серії.

Тому в якості математичної моделі можна запропонувати наступне вираження:

$$
\frac{d V_{\text {вих }}}{d t}=f\left(V_{\text {вих }}(t), S_{\text {вх }}(t)\right)
$$

де $V_{\text {вих }}(t)$ - сумарний показник вихідних параметрів системи; $S_{\text {вх }}(t)$ - вхідний інформаційний показник системи.

Висновки та перспективи подальших досліджень

1. Розроблена математична модель контролю ПФС машиніста локомотивного складу.

2. Запропонована методика діагностування ПФС за допомогою обробки мовного сигналу що дозволяє доступно і надійно контролювати стан машиніста як на ближньому, так і далекому відстань в течії робочої зміни.

3. Дані рекомендації відносно поліпшення продуктивності праці і зменшення аварійності в екстремальних умовах роботи.

4. Розглянуті варіанти поліпшення системи контролю завдяки зміні контрольованих параметрів для конкретної галузі виробництва.

\section{Список використаної літератури}

1. Психофизиология профессиональной деятельности / сост. Ю. Н. Лачугина. - Ульяновск: УлГТУ, 2014. $-92 \mathrm{c}$.

2. Фрай О. Детектор лжи и обмана. - СПб: Прайм - еврознак, 2005. - 320 с.

3. Минкин В.А. Виброизображение. - СПб.: Реноме, 2007. - 108 с.

4. Russian patent RU 2289310 a priority $19.12 .2000 \mathrm{~g}$. «Method of obtaining information about the psycho - physiological state of a living object». MINKIN V.A., SHTAM A.I.

5. P. D. Cremer, G. M. Halmagyi, S. T. Aw, I. S. Curthoys, L. A. McGar-vie, M. J. Todd, R. A. Black and I. P. Hannigan. Semicircular canal plane head impulses detect absent function of individual semicircular canals // Brain. Vol. 121. Issue 4. 1998 P. 699-716.

6. Экман П. Узнай лжеца по выражению лица / Пер. с анг. - СПб.: Питер, 2013 - 272 с.

7. Blouin C., Maffiolo V. A study on automatic detection and characterization of emotion in voice service context, Interspeech 2005, France Telecom, R\&D Division, France, 2005. Pp.51-56.

8. Ververidis D. and Kotropoulos. C. A review of emotional speech databases // Proc. Panhellenic Conference on Informatics (PCI). Thessaloniki, Greece. 2003. pp. 560-574.

9. Geladze N.V. Modifikaciyaintonacionnojstrukturypovestvovatel'nojfrazy pod vliyaniemehmocional'nojokraskivofrancuzskomyazyke // Sb. nauch. tr. Vyp. 84. M.: MGPIIYAim. M. Toreza, 1975.

10. Викторов А.Б., Остроухов А.В., Лобанова М.А. О возможности создания автоматизированного комплекса диагностирования учетных признаков // Информатизация и информационная безопасность правоохранительных органов. Сб. трудов XV Международной научной конференции. 23-24 мая 2006 г. М.: Академия управления МВД России, 2006. С. 328-331.

11. Потапова Р.К., Потапов В.В. Перспективы развития концепции «речевой портрет говорящего» // Сб. трудов XVII Международной научной конференции «Информатизация и информационная безопасность правоохранительных органов». М.: Академия управления МВД России, 2008. С. 125-126. 